\title{
Lina Zinchenko
}

post-graduate student of Pedagogical Sciences, Professor, Pedagogy and Psychology of Social Systems Management Department of the academician I. A. Ziaziuna, National Technical University

"Kharkiv Polytechnic Institute"; Kharkiv, Ukraine

ORCID: 0000-0001-7927-3535

E-mail: likusanka@gmail.com

\section{A STUDY OF PEDAGOGICAL CONDITIONS FOR DEVELOPMENT OF PROFESSIONAL RESPONSIBILITY AMONG PHYSICAL TRAINING AND SPORTS PROFESSIONALS}

Abstract: the article discusses pedagogical conditions of the development of professional responsibility among the students of physical training and sports. In it, the notions «pedagogical conditions» and «professional responsibility» are defined and surveyed; examples of pedagogical conditions analysis from the most recent academic publications on the topic are analyzed. The study assumes that the development of professional responsibility among the students of physical training and sports remains one of the most significant aspects of the teaching process during their study in higher education establishments.

Key words: pedagogical conditions, professional responsibility, physical training and sports, students, higher education.

\section{Ліна Зінченко}

аспірант, кафедра педагогіки і психології управління соціальними системами ім. I.A. Зязюна, Національний технічний університет "Харківський політехнічний інститут", Харків, Україна

ORCID: 0000-0001-7927-3535

E-mail: likusanka@gmail.com

\section{ПЕДАГОГІЧНІ УМОВИ ФОРМУВАННЯ ПРОФЕСІЙНОЇ ВІДПОВІДАЛЬНОСТІ МАЙБУТНІХ ФАХІВЦІВ ФІЗИЧНОЇ КУЛЬТУРИ І СПОРТУ}

Анотація: розглянуто педагогічні умови формування професійної відповідальності майбутніх фахівців фізичної культури і спорту. Розкриті поняття “педагогічні умови”, “професійна відповідальність”. Проаналізовані наукові літературні джерела i наведені педагогічні умови, що виділені сучасними науковцями з педагогіки, психології, соціології, права. Доведено, що формування професійної відповідальності у майбутніх фахівців з фізичної культури і спорту у закладах вищої освіти є одним із важливих аспектів виховання та навчання.

Ключові слова: педагогічні умови, професійна відповідальність, фізична культура і спорт, майбутні фахівці, освіта. 


\title{
ПЕДАГОГИЧЕСКИЕ УСЛОВИЯ ФОРМИРОВАНИЯ ПРОФЕССИОНАЛЬНОЙ ОТВЕТСТВЕННОСТИ БУДУЩИХ СПЕЦИАЛИСТОВ ФИЗИЧЕСКОЙ КУЛЬТУРЫ И СПОРТА
}

\begin{abstract}
Аннотация: в статье рассматриваются педагогические условия формирования профессиональной ответственности будущих специалистов физической культуры и спорта. Раскрыты понятия “педагогические условия", «профессиональная ответственность». Проанализированы научные литературные источники и приведены педагогические условия, выделенные современными учеными по педагогике, психологии, социологии, права. Доказано, что формирование профессиональной ответственности у будущих специалистов по физической культуре и спорту в учреждениях высшего образования является одним из важных аспектов воспитания и обучения.

Ключевые слова: педагогические условия, профессиональная ответственность, физическая культура и спорт, будущие специалисты, образование.
\end{abstract}

\section{Ліна Зинченко}

Розширена анотація для ознайомлення з цією темою:

“Педагогические условия формирования профессиональной ответственности будущих специалистов физической культуры и спорта"

\begin{abstract}
Постановка
проблеми

загальному вигляді та ї̈ зв'язок із важливими науковими чи практичними завданнями. За останній час в Украӥні активно проходить європейська реформа вищої освіти, шуо змушує все більше уваги приділяти питанню підготовки фахівиів. Не оминуло це питання $i$ сфреру фізичної
\end{abstract} культури $i$ спорту. $У$ освітньопрофесійній програмі вищої освіти, спеціальності "Фізична культура $i$ спорт” прописані загальні компетентності, фахові компетентності та компетентності спеціалізації, якими повинен оволодіти майбутній фахівець. Бути компетентним фахівием че лише пів справи, потрібно бути і професійно відповідальним, саме тоді ией тандем надасть великі шанси для досягнення успіху і стрімкого підйому до професійного Олімпу.

Зрощуючи нове покоління фахівців у закладах вищої освіти, викладач завжди знаходиться у пошуку нових, ефективних педагогічних умов розвитку чи формування тих, чи інших професійно необхідних якостей особистості фахівия. Пошук ефективних педагогічних умов для формування професійної відповідальності майбутніх фахівиів фізичної культури $i$ спорту є актуальним напрямком.

Аналізуючи поставлену проблему можна побачити, щзо педагогічні умови розглядають у різних наукових витоках: педагогіки, психології, соиіології, юридичної справи, менеджменту, у деяких природничих науках (медииина, екологія).

Аналіз останніх досліджень $\boldsymbol{i}$ публікацій, у яких започатковано розв'язання иієї проблеми $i$ на які спирається автор. Аналізуючи науководослідну педагогічну літературу щьодо формування професійної відповідальності майбутніх фахівців,можна зазначити про необхідність впровадження у навчальний прочес нових педагогічних умов формування професійної відповідальності майбутніх фахівців фізичної культури $i$ спорту: забезпечення гуманних засад, $a-$ саме застосування діалогового підходу, 
впровадження особистісно орієнтовного навчання; підвищення мотивації студентів до формування професійної відповідальності, оволодіння професійними знаннями $і$ розвиток моральних якостей; оновлення навчальної програми через удосконалення змісту навчальних дисциилін $i$ забезпечення $\ddot{i x}$ практичної спрямованості.

Під педагогічними умовами науковиі (О. Кочерга, О. Дурманенко, Н. Хромченкова, С. Букиа,

Л. Сатановська, I. Сопівник та інші) розуміють сукупність обставин, факторів, вимог, впливів, які позитивно позначаються на освітньому прочесі.

Виділення не вирішених раніше частин загальної проблеми, котрим присвячується дана стаття. 3 а результатами теоретичного дослідження було встановлено, щзо $\epsilon$ багато досліджень присвячених педагогічним умовам формування професійної відповідальності, в яких пропонують різноманітні моделі реалізації педагогічних умов. Але поза

Problem setting. Of its relation to the most significant academic tasks and practice. Currently, when the European reform of higher education is being pursued in Ukraine, the local educators tend to devote more and more attention to pedagogical conditions of professional training of their students. The problem is becoming the object of active discussion among teachers of physical training and sports. According to The Educational and Professional Program of Higher Education, the specialization 017 "Physical Training and Sports", which suggests general characteristics and expert requirements of professional competence for the future professionals, being a competent professional is just a part of the professional competence, but professional maturing and final expertise also depends on professional responsibility of the specialist.

While working on professional maturing of every new generation of увагою науковизів залишається

формування професійної відповідальності майбутніх фахівців фізичної культури $i$ спорту у закладах вищчої освіти.

Формулювання цілей статmі (постановка завдання). Метою статmі $\epsilon$ теоретичний аналіз педагогічних умов, шуо забезпечують ефективне формування професійної відповідальності майбутніх фахівців фізичної культури $i$ спорту $y$ закладах вищуої освіти.

Висновки з даного досліджсеня та перспективи подальших розвідок $y$ даному напрямку. Прочес формування професійної відповідальності майбутніх фахівців фізичної культури $i$ спорту $\epsilon$ досить складним і повинен здійснюватись поетапно. Особливістю професійної відповідальності під час формування майбутніх фахівців фізичної культури $i$ спорту є розуміння сутності професійної відповідальності; у усвідомлення важливості виконання професійних обов'язків; знання з фахової підготовки; передбачення результатів $i$ наслідків діяльності.

professionals, the higher education professionals never stop looking for new, more effective pedagogical conditions that could influence the development of the most relevant professional qualities of the young specialists. Thus, the search for the most effective pedagogical conditions that can enhance the development of the students' professional responsibility remains an important trend in the work of educators.

Recent research and publications analysis. Which offer solutions to the problem and thus, have created the basis, on which this study is grounding. The general survey of the problem reveals the fact that the notion "pedagogical conditions" frequently becomes the object of discussion among educators (O. Kocherga, O. Durmanenko, N. Chromchenkova, S. Buksha, L. Satanovska, O. Romanovsky, N. Boreyko, and others), as well as in works of psychologists, social workers, law 
professionals, management experts, and some representatives of the Earth sciences (medicine, ecology, etc.). The problem of professional responsibility was studied by O. Titarenko, V. Andruschenko, G. Ionas, G. Lozhkin, M. Marmadashvili, O. Orehovsky, A. Platonova, O. Plahonty, P. Reeker, L. Baranovska, O.Korneva and others; Psychological aspects of professional responsibility are touched upon by O. Patynok, K. Mudzibayeva, L. OrlanLembrik, M. Savsyn, I. Tymoschuk, Yu. Trofymov, V. Rybalko, P. Honcharuk and others; A significant input into the study of responsibility was made by methodology experts O. Ponomaryova, M. Chebotaryova, N. Sereda, I. Bekh, S. Honcharenko, H. Sozykina, I. Sopivnyk, I. Zyazyun, I. Isayev, V. Kremen, O.Moyko, I. Gamulya and others. Responsibility as an inseparable quality of a professional's personality was studied by N. Boreyko, L. Azarenkova, O. Romanovsky, T. Rymareva, L. Gren, I. Svezhentseva and others. Also, responsibility of a teacher is being actively studied by H. Vasyanovych, M. Smetansky and others, and responsibility of the students is described in the works of L. Tytomyr, V. Ternopilska and others.

The problem of development of professional responsibility was surveyed by the military field educators as well: I. Hamula, I. Korobeynikova, L. Blukhman, L. Arhangelskiy and others. The scientists V. Malinovska, O. Ivanenko, V. Golovchenko, L. Kryveno, V. Honcharenko, L. Nalyvayko and others. Identifying previously unresolved parts of the general problem. According to our theoretical survey, there is a variety of approaches to the study of pedagogical conditions of professional responsibility, where models of realization of the pedagogical conditions are suggested. However, the problem of professional responsibility development among the future specialists in physical training and sports, who are taking their graduate course at establishments of higher education, remain beyond scientists' focus of attention.

Paper objective. Is to provide theoretical analysis of pedagogical conditions that ensure effective development of professional responsibility of the physical training and sports students at establishments of higher education.

Paper main body. To ensure better understanding of the study, let's define the term "condition" first.

The Ukrainian Interpretative Dictionary offers the following definition of a condition: "it is a necessary circumstance that makes it possible to change, affect, create or promote something" [5 p. 632]; "Circumstance (external or internal) on which something depends"; "what depends on the rest" [2].

Pedagogical conditions are external circumstances influencing the achievement of educational goals in a higher education institution [9 p. 245].

In her research, I. Sopivnik studied types of responsibility and suggested pedagogical conditions of moral responsibility development among rural youth; she also confirmed the effectiveness of the approach in her research. I. Sopivnik, identified professional responsibility of a person as a "complex psychological pattern that implies a conscious choice of professional activity that meets personal characteristics of the individual ... ability to anticipate the consequences of professional activity in the conditions of sustainable development, taking responsibility for the quality and safety of products or services provided to themselves, their team, the community they live in, and the society in general" [9 p. 62, 303].

Writing about pedagogical conditions, O. Kocherga regards them as a set of circumstances, factors, requirements and influences which create a positive impact on the teaching process. The author suggests a set of pedagogical conditions for the future teachers' social responsibility development, which support considerable increase in the 
young teachers' social responsibility. The author proposes to implement the approach by means of improving educational potential of disciplines, by focusing pedagogical practice on the development of responsible behavior skills, and by development of social responsibility through extracurricular activities, which are regarded as an important component of students' education" [4]. As for the curriculum, O. Kocherga identified a number of disciplines that are directly aimed at the development of the future specialists' professional competence; within this approach, social responsibility takes a significant place.

In her research, O. Durmanenko identifies pedagogical conditions as sets of organizational measures taken within the teaching process of a higher educational establishment, which determine the results of teaching, learning and the development of a student's personality that objectively ensure their achievement [2, c. 136]. In her research, the author analyzed pedagogical conditions within the context of monitoring the teaching process in a university. In her research, the author also defines professional skills and certain personal traits of a future specialist.

N. Hromchenkova studied the question of the future journalists' professional responsibility development, she laid the basis for studying of the following pedagogical conditions: "Creation of favorable conditions for self-actualization, self-growth, self-esteem, training in the conditions of subjective-subjective interaction, which implies the free choice of the way of obtaining education; students' readiness to solve problematic tasks; use of interactive methods of training to activate the cognitive activity of subjects; formation of information culture of future journalists" [10, c. 121].

S. Buksha studied a set of pedagogical conditions that influence development of professional responsibility among teachers. In his publications, the accent is made on the statement that "the process of development of professional responsibility should be based on interaction of personality (subjective understanding of responsibility) and the profession (the objective professional requirements to the teacher's professional activity)" [1].

L. Satanovska proposes to develop professional responsibility of the future managers in the sphere of education within a higher education institution under the following pedagogical conditions: "motivation of responsible behavior; professional orientation of the future specialist; the teachers' pedagogical skills; providing efficient training for the future education managers" $[8$, c. 68$]$.

In the works of O. Ponomaryov and his co-authors, define notions of professional responsibility as follows: professional responsibility "lies in acceptance by a person of his/her profession and professional activity as one of the most significant lifetime values, and in realizing of its importance for the society" [6, c. 15].

We also identified the notion of professional responsibility: this is a quality of personality that allows to realize the essence and the importance of professional activity; understanding and competent fulfillment of a person's professional duties; preparedness to take responsibility for the results of his/her actions and decisions [7].

The analysis of research and scientific literature on development of professional responsibility of the future specialists, proves the necessity of implementation of the following new pedagogical conditions into the process of teaching professional responsibility of the future physical training and sport specialists, namely: application of effective communication approach, introduction of person-oriented teaching; enhancement of students' motivation for development of professional responsibility, development of professional competence and highly moral attitude to work; implementation of innovative approaches to teaching, upgrading informational and methodological components of every 
discipline, and providing enhanced professional training.

The pedagogical conditions for development of physical training and sport professionals were created by means of implementation of the abovementioned features: introduction of effective communication approach, introduction of person-oriented teaching. Taking into account the role of professional responsibility in the work of a specialist in physical training and sports, the students began to develop their own, individual concepts of professional responsibility, evaluate its role and structure, as well as to realize the place of responsibility within the structure of professional competence. Under the influence of the proposed system of training, a student became a participant of the teaching process, while the teacher conducted continuous dialog with the student, demonstrating understanding, cooperation, and loyalty to the student's thinking process, thus, creating the environment of friendly, creative, ongoing dialog.

Another important condition is students' motivation for the development of professional responsibility, knowledge accumulation and development of professional ethics. Motivation is a person's desire to undertake certain activities in order to satisfy his/her needs. There are different types of motivation, but the important thing is to learn how to develop and keep high level of motivation, which is based on the student's awareness of the need for learning and on his/her individual system of values. Traditionally, the students' motivation for professional study begins with the course of discipline called "Introduction into Your Specialty", which aims to form a holistic view of the future profession, activity associated with it, and to outline the system of preparation for it. This system is grounded on fundamental principles of education, first of all, on the didactic rules accepted by higher education system, and thus it is very efficient. In our research, the discipline was taught on the basis of the latest achievements of pedagogical theory, educational practice, with understanding of modern realities, the state and place of the profession in the job market, and the core tendencies and potential of its development in the future.

It is necessary to mention one more pedagogical condition for development of professional responsibility of the future physical training and sport professionals: it is continuous improvement of the teaching program by means of upgrading every discipline and ensuring their practical orientation. To resolve the task, we introduced a discipline called "Professional responsibility within the sphere of physical training and sport"; a methodology for it was developed and introduced into the teaching process; as a next step, a coursebook "Responsibility Within the Sphere of Physical Training and Sport" for teachers and students of Physical Training and Sport was put into practice; a coursebook "Professional Responsibility in Sports Training" for teachers and students of Physical Training and Sport was introduced into the teaching process; also, introduction of certain topics on professional responsibility into the programs of such disciplines as "Introduction into Profession", "Theory and Methodology of Physical Training", "The Art of Teaching", "Pedagogy", "Pedagogy of Higher Education" were provided.

Conclusions of the research. The process of professional responsibility development is quite complex, it should be taught to the future specialists in physical training and sports in stages. The peculiarity of professional responsibility development among the future specialists of physical training and sports, lies in their understanding of the essence of professional responsibility; in awareness of the importance to fulfill their professional responsibilities; in sufficient professional training; in the ability to predict the results and consequences of professional activity.

Among the important pedagogical conditions of professional responsibility development among the future specialists in 
physical training and sports are the following factors: effective communication approach, person-oriented teaching, students' motivation for development of professional responsibility, professional competence and moral attitude to their professional

\section{Список літератури:}

1. Букша С. Б. Теоретичне обгрунтування педагогічних умов формування професійної відповідальності майбутніх учителів основ здоров'я / С. Б. Букша // Вісник Луганського національного університету імені Тараса Шевченка. Педагогічні науки. - № 5(2). 2014. - С. 139 - 146

2. Дурманенко О. Теоретичний аналіз поняття "педагогічні умови" в контексті моніторингу виховної роботи у вищому навчальному закладі / О. Дурманенко // Молодь і ринок. - № 7(90). - 2012. - С. $135-138$

3. Zinchenko, L. (2020), "The main responsibilities of a specialist in physical culture and sports in today's society", "Dynamics of the development of world science", Abstracts of the 6th International scientific and practical conference, Vancouver, Canada: Perfect Publishing, pp. $571-575$, available at: http://sciconf.com.ua

4. Кочерга О. М. Формування соціальної відповідальності у студентів педагогічного коледжу / О. М. Кочерга // Дис....канд. педагог. наук: спец. 13.00.07 "Теорія та методика виховання". - Ніжин. 2012. - C. 285

5. Новий тлумачний словник української мови: у 4 Т. - К.: Аконіт. T.2. 1999. - C. 632

6. Пономарьов О. С., Середа Н. В., Чеботарьов М. К. Відповідальність як педагогічна категорія / О. С. Пономарьов, Н. В. Середа, М. К. Чеботарьов // Навч.метод. посіб. - Харків: Вид-во Підручник НТУ "ХПІ". - 2013. - С. 172

7. Пономарьов О. С., Зінченко Л.В. Професійна відповідальність у спортивній педагогіці / О. С. Пономарьов, responsibilities; as well as implementation of innovative approaches to teaching, upgrading informational and methodological components of every discipline, and providing enhanced professional training.

Л. В. Зінченко // Навч. посіб. - Харків: НТУ "ХПІ". Видавець О. А. Мірошниченко. - 2019. - С. 200

8. Сатановська Л. Формування професійної відповідальності майбутніх менеджерів освіти в умовах вищого навчального закладу [електронний ресурс] / Л. Сатановська // Вісник Київського національного університету імені Тараса Шевченка. Педагогіка. Вип. 1. - 2015. - С. 65 - 70. - Режим доступу:http://nbuv.gov.ua/UJRN/vknutshp _2015_1_18

9. Сопівник I. В. Виховання моральної відповідальності сільської молоді / І. В.Сопівник // Монографія. - К.: "ЦП “Компринт”. - 2014. - С. 352

10. Хромченкова Н. М. Педагогічні умови формування професійної відповідальності майбутніх журналістів. Науковий журнал "Молодий вчений". № 12 (64) грудень. - 2018. - С. 119 - 123

\section{References:}

1. Buksha, S.B. (2014), "Theoretical substantiation of pedagogical conditions of formation of professional responsibility of future teachers of the basics of health", Visnyk Luhanskoho natsionalnoho universytetu imeni Tarasa Shevchenka, Pedahohichni nauky, no. 5(2), pp. $139-146$
2. Durmanenko,
O.
(2012), "Theoretical analysis of the concept of "pedagogical conditions" in the context of monitoring educational work in higher education", Molod i rynok, no. 7(90), pp. $135-138$

3. Zinchenko, L. (2020), "The main responsibilities of a specialist in physical culture and sports in today's society", "Dynamics of the development of world science", Abstracts of the 6th International 
scientific and practical conference, responsibility in sports pedagogy", Navch.

Vancouver, Canada: Perfect Publishing, pp. Posib, Kharkiv: NTU "KhPI", Vydavets $571-575$, available at: http://sciconf.com.ua

O. A. Miroshnychenko, p. 200

4. Kocherha, O. M. (2012),

8. Satanovska, L. (2015), "Formation "Formation of social responsibility among education managers in higher education", students of the pedagogical college", Dys....kand. pedahoh. nauk: spets. 13.00.07 "Teoriia ta metodyka vykhovannia", Nizhyn, p. 285

5. "New Ukrainian Dictionary of Interpretation: $4 \mathrm{~T}$ ” (1999), K.: Akonit, t. 2. p. 632

6. Ponomarov, O. S. Sereda, N. V., Chebotarov, M. K. (2013), "Responsibility as a pedagogical category", Navch.-metod. posib, Kharkiv: Vyd-vo Pidruchnyk NTU "KhPI", p. 172 Visnyk Kyivskoho natsionalnoho universytetu imeni Tarasa Shevchenka, Pedahohika, vol. 1, pp. $65-70$, available at: http://nbuv.gov.ua/UJRN/vknutshp_2015_1_ 18

9. Sopivnyk, I. V. (2014), "Education of moral responsibility of rural yout", Monohrafiia, K.:’TsP “Komprynt”, p. 352

10. Khromchenkova, N. M. (2018), "Pedagogical conditions of formation of professional responsibility of future journalists", Naukovyi zhurnal "Molodyi 7. Ponomarov, O. S., Zinchenko, L. V. (2019), "Professional vchenyi", no. 12 (64) december, pp. 119 123

Стаття надійшла до редколегї 13.03.2020 